\title{
SMALL AND MEDIUM ENTERPRISES NEED AND PROBLEMS - A STUDY WITH REFERENCE TO IN AND AROUND PUNE CITY OF MAHARASHTRA
}

\author{
Mr. Milind Jagtap \\ Chief Mentor \& Chairman - SOFTHARD Automation Pvt. Ltd. \\ 19, Indu Building, Chittavahari Society, \\ Dhankawadi, Pune - 411043
}

\begin{abstract}
The new industrial policy statement announced on July 24, 1991, has reiterated the importance of the small scale sector. As a sequel to that, the government of India announced policy measures for promoting and strengthening small, tiny and village enterprises on August 6 1991, to provide further impetus and growth to the small sector. As per the policy statement, the primary objective of the small scale industrial policy during the nineties would be to impact more vitality and growth to the sector to enable it to contribute its mite fully to the economy particularly among woman, enactment of suitable legislation to ensure prompt payment of small industrial bills introduction of limited partnership Act to enhance supply of risk capital to small scale sector, implementation of special schemes for modernization, technology up gradation and quality control, integrated infrastructural development and further promotion of internal marketing and exports are some of the measures outlined in this policy.

In this paper an attempt is made to study the need of SMEs and its problems in India considering the limitations of time, money and resources, the study is conducted in and around Pune city of Maharashtra state. As Pune is the industrial hub of Maharashtra. The study claims to be representative study.
\end{abstract}

Key words : SMEs, Modernization, technology up gradation, quality control, partnership act.

\section{INTRODUCTION}

The new industrial policy statement announced on July 24, 1991, has reiterated the importance of the small scale sector. As a sequel to that, the government of India announced policy measures for promoting and strengthening small, tiny and village enterprises on August 6 1991, to provide further impetus and growth to the small sector. As per the policy statement, the primary objective of the small scale industrial policy during the nineties would be to impact more vitality and growth to the sector to enable it to contribute its mite fully to the economy particularly among woman, enactment of suitable legislation to ensure prompt payment of small industrial bills introduction of limited partnership Act to enhance supply of risk capital to small scale sector, implementation of special schemes for modernization, technology up gradation and quality control, integrated infrastructural development and further promotion of internal marketing and exports are some of the measures outlined in this policy.

In this paper an attempt is made to study the need of SMEs and its problems in India considering the limitations of time, money and resources, the study is conducted in and around Pune city of Maharashtra state. As Pune is the industrial hub of Maharashtra. The study claims to be representative study.

To provide access to the capital market and to encourage modernization and technological up gradation, equity participation by other industrial undertakings in small scale industries not exceeding $24 \%$ of the total share holding is proposed to be allowed. It is proposed to widen the scope of the national equity found scheme and single Window scheme and to make composite loan under the single window also available through commercial banks. While small scale sector would be mainly entitled for onetime benefit, tiny enterprises would be eligible for additional support on a continuing basis including easier access to industrial finance, priority in Government purchase programmed and relaxation from certain provisions of labour laws. And above all, rules and procedures applicable to small scale units would be further simplified.

The industrial policy resolution, 1956 emphasized the role of village and small scale industries and the spelt out the aim of policy which would be to ensure that the decentralized sectors acquires sufficient vitality to be self supporting and its development is integrated with that of large scale industry. The resolution stated that the Government of India would stress the role of cottage and village and small scale industries in the development of the national economy. In the relation to some of the problems that need urgent solution, they offer some distinct advantages. They provide immediate large scale employment, they offer a method of ensuring more equitable distribution of the national income and they facilitate an effecting mobilization of resource of capital and skill which might otherwise remain unutilized. Some of the problems that unplanned urbanization tends to create will be avoided by the establishment of small centers of industrial production all over the country.

The Govt. of India, through its Ministry of commerce \& industry in collaboration with the planning 
commission and through the courtesy of ford foundation. Invited an international planning team to study opportunities directed towards increasing both industrial production and employment of people. The team studied the commendable efforts that have been made to assist small industries these efforts have been largely sporadic and have dealt chiefly with isolated segments of the problem. Lacking a systematic approach, they fall short of making by appreciable impact towards the overall advancement of industrials development and no satisfactory overall solution or appreciable progress can be expected from them.

The Govt. of India took note of the various recommendations made by the team for an orderly development of small scale industries and this was sought to be implemented during the second five year plan. The basic approach of the plan was to assign higher priority and larger role to the development of basic industries for the manufacture of producer goods, and also to accelerate the expansion of economic overheads like transport and power as well as social overheads like health, education and social services. The consumer demand arising from the increased expenditure in these sectors of the national economy is to be met substantially by the development of village and small scale industries, which on the hand, will not make any heavy demand on the scarce capital resources available within the country, and on the other, will provide increasing employment opportunities.

\section{DEFINITION OF SME SINCE 1950}

The definition of small scale industries has undergone changes over the years in terms of investment limits in the following manner. ${ }^{1}$

Now-a-days Indian Small and Medium Enterprises are mostly modern small-scale industries. Modernization has widened the list of products offered by this industry. The items manufactured in modern smallscale service and business enterprises in India include rubber products, plastic products, chemical products, glass and ceramics, mechanical engineering items, hardware, electrical items, transport equipment, electronic components and equipments, automobile parts, bicycle parts, instruments, sports goods, stationery items and clocks and watches.

Earlier SMEs were defined on the basis of number of employees, sector of operation and incurred intensity of investment. SMEs in India are of two types: manufacturing and service providers. MSME sector is a growth engine powered by less investment, mobility, flexibility and substitution. MSMED act 2006 (Micro Small Medium Enterprises Development) introduced the concept of medium or micro enterprises. Under this act the limited industries have been widened to that of enterprises (Ghatak 2010). The small scale industries are defined as per following division.
Table 1

Evaluation of Investment Limits for SSI

\begin{tabular}{|c|c|c|}
\hline Year & Investment Limits & $\begin{array}{l}\text { Additional } \\
\text { Conditions }\end{array}$ \\
\hline 1950 & Up to Rs.5.0 lakh in fixed assets & $\begin{array}{l}\text { Less than } \\
50 / 100 \\
\text { persons } \\
\text { with or } \\
\text { without } \\
\text { power }\end{array}$ \\
\hline 1960 & Up to Rs.5.0 lakh in fixed assets & $\begin{array}{l}\text { No } \\
\text { condition }\end{array}$ \\
\hline 1966 & Up to Rs.7.5 lakh in Plant \& Machinery & $\begin{array}{l}\text { No } \\
\text { condition }\end{array}$ \\
\hline 1975 & Up to Rs.10 lakh in Plant \& Machinery & $\begin{array}{l}\text { No } \\
\text { condition }\end{array}$ \\
\hline 1980 & Up to Rs.20 lakh in Plant \& Machinery & $\begin{array}{l}\text { No } \\
\text { condition }\end{array}$ \\
\hline 1985 & Up to Rs.35 lakh in Plant \& Machinery & $\begin{array}{l}\text { No } \\
\text { condition }\end{array}$ \\
\hline 1991 & Up to Rs.60 lakh in Plant \& Machinery & $\begin{array}{l}\text { No } \\
\text { condition }\end{array}$ \\
\hline 1997 & $\begin{array}{l}\text { Up to Rs. } 300 \text { lakh in Plant \& } \\
\text { Machinery }\end{array}$ & $\begin{array}{l}\text { No } \\
\text { condition }\end{array}$ \\
\hline 1999 & $\begin{array}{l}\text { Up to Rs.100 lakh in Plant \& } \\
\text { Machinery* }\end{array}$ & $\begin{array}{l}\text { No } \\
\text { condition }\end{array}$ \\
\hline 2001 & $\begin{array}{l}\text { Up to Rs.100 lakh in Plant \& } \\
\text { Machinery* }\end{array}$ & $\begin{array}{l}\text { No } \\
\text { condition }\end{array}$ \\
\hline
\end{tabular}

Source: Ministry of Industry, Government Of India

* With effect from October 2001, the investment ceiling in Plant \& Machinery in respect of 41 items covering two broad groups of Hosiery \& Hand Tolls has been enhanced to Rs.500 lakh.

2.1 Manufacturing Enterprises

These are into production or manufacturing of goods of an industry and count investment in machinery and plant. Their categories are:

2.1.1 Micro Manufacturing Enterprises - up to Rs. 25 lakhs.

2.1.2 Small Manufacturing Enterprises- Above Rs. 25 lakhs and up to Rs. 5 Crores.

2.1.3 Medium manufacturing Enterprises- Above Rs. 5 Crores and up to Rs. 10 Crores.

\subsection{Service Enterprises}

These are into delivery of services and count investment in equipment. Their categories are:

\subsubsection{Micro Service Enterprises- Up to}

Rs. 10 lakhs.

\subsubsection{Small Service Enterprises- Above}




$$
\text { Rs. } 10 \text { lakhs and up to Rs. } 2 \text { crores. }
$$

\subsubsection{Medium Service Enterprises- Above \\ Rs. 2 Crores and up to Rs.5 Crores}

\section{CATEGORIES IN SMALL SCALE SECTOR}

There are different segment or categories in small scale sector playing very important roles. The first category has specialized in traditional commodities. These commodities are produced out of the natural raw materials and traditional tools. Handicrafts manufacturing traditional and artistic products are good examples of this category. The second category is industries which manufacture modem commodities by labour intensive methods. These industries have begun to use factory raw materials but the means of production remains traditional. Manufacture of matches, soap etc., can be included in this category. The third category comprises modern units. These units employ power, raw materials and modern means of production to produce modern products. Before rapid industrialization could take roots in our country, the first two categories dominated the small scale production. The domination was possible because many social and economic factors compelled the government to pay primary attention to the expansion of industries in the first two categories.

\section{NEED FOR SMALL AND MEDIUM ENTREPRISES}

The following points further demonstrate the importance of Small and Medium Enterprises:

\subsection{Creating Employment}

A developing country like ours is characterized by a rapidly growing population and labor force. Absorbing the labor force in productive employment is one of the principle challenges of development. Apart from the unemployment problem, under employment also will have to be tacked in a better manner. Existence of a large volume of unemployment creates a very serious situation in the country.

A large number of unemployed and under employed persons indicated wastage of available resources of manpower and in terms of distribution it creates very large problems of low income groups living much below any recognized subsistence level. It is unlikely that large scale industry will use labor intensive methods of production. Moreover, small firms, lacking the capital resources of the larger firms and using older machines, are likely to be forced to use such methods. This will probably lead to greater employment per unit of output than if the same product were produces entirely in large scale plants.

In a labor surplus economy like ours where the capital is short, Small and Medium Enterprises because of labor intensity can afford to provide employment to many people. Labor has to be looked upon as a valuable resource, and its continued underutilization points to defective planning, second, unemployed people are a social liability in a society whose conscience is sufficiently aroused, and as a poor country with large volume of underemployment or unemployment has not got the resource to grant public assistance to those in distress, the planning for employment of all becomes a doubly important objective.

\subsection{Regional Development}

Regional growth is almost inevitably unbalanced, some regions are better endowed with resources than other, investment in lumpy and many projects have to be undertaken on a large scale at a very limited number of locations ( due to demand constraints ) to be economical; external economies provide a strong motive for agglomerating industrial investment at selected locations; markets are not distributed evenly, and this results in inter-regional imbalance in transport development, and market oriented industries.

The government of India's concern regarding the industrial imbalance stated in the industrial policy resolution, 1948, when it said that industrial development has so far been on unplanned basis and it has been concentrated in a few select areas. The excessive concentration of industries brings in its train certain economic and social disadvantages and a wider diffusion of industry is desirable.

Small and Medium Enterprises can be used as an instrument in bringing about a balanced regional development, by a setting up Small and Medium

Enterprises in backward areas and rural areas, the units can give employment to the local people there and at the same time cater to the distant and remote markets. A realization of the essential life in an egalitarian democracy would emphasis the need for a re-orientation of our attitude towards the further growth of some of our large cities.

The promotion and development of small enterprises on a dispersed basis is an important objective of development policy. Small industries by themselves cannot be expected to initiate the process of industrial dispersal beyond the metropolitan areas. As such, comprehensive development schemes should be initiated on an integrated basis in selected areas and centers to provide infrastructure and related facilities together with critical inputs for the sustained development of small scale and other industries in semi-urban centers which can serve as focal points of agro-industrial development.

\subsection{Promotion of entrepreneurship}

Economic growth requires more and more men with personal qualities of initiative and leadership, combined with skill in organizing and managing. Channels are needed by which suitable talented and motivated individuals can find their way to new and constructive types of economics achievement. Small and Medium Enterprises manufacturing can provide one such channel. As small scale entrepreneurs cannot hire the services of professional managers to run their units, they themselves have to manage the units in a manner, which 
they deem fit according to the existing business conditions. By managing small- scale units. The entrepreneurs are able to learn many things out of their experience. In course of time, the entrepreneurs acquire invaluable experience and they are prepared to manage and business. Before becoming entrepreneurs, they are very much like other ambitions striving individuals.

Entrepreneurs play a key role in the determining levels and rates of economics development among a complex of inter related factors. Not only do entrepreneurs exploit the profit opportunities generated by the economy, but their action may create such opportunities for others and there by more the economy.

Rapid economic progress in developing countries calls for the willingness engineer change. A growing and continuous supply of new entrepreneurs to establish and manage small and medium sized industries offers a remarkable single solution to many critical problems that confront us today. Apart from providing productive employment to the increasing ranks of the unemployed, educated to uneducated, it will help the process of dispersing economic growth. Thus Small and Medium Enterprises provide productive outlets for the talents and energies of enterprising, independent people many of whom would not fulfill their potential in large organizations.

\subsection{Channelizing Savings}

The saving of the middle classes and affluent sections of the society cannot be tapped so easily by large firms or $y$ other institutions. If these sections of the society are encouraged, the entrepreneurs will bring along with them a substantial amount of their savings to be invested in the small scale units. Thus, small industry is also capable of contributing to the formation of material capital. In doing so, it taps sources of capital which would not be tapped by large firms or by any means other than independent entrepreneurship.

\subsection{Reducing disparity of Wealth and Income}

Concentrated economic power is considered to be an evil when the great disparity of wealth and income between a small sections of the society exerting such power, where as the majority live in object poverty. This small section is able to possess such power because of the rise of big business. We must recognize the fact that big business has done much for the country's industrial development, but in the process has strengthened the hands of small sections. Promotions of the Small and Medium Enterprises are of some importance in combating the effects of concentrations.

\subsection{Assistance to Small and Medium Enterprises}

Recognizing the importance of the Small and Medium Enterprises, the Government of India had launched a comprehensive programme of assistance for speedy development of small scale industries at all stages of production ranging from selection of line of production to marketing of the final product. The small industries development organization with its network of 25 small industries service industries, 18 Branch institutes, 41 extension centers, 4 Regional testing centers, One product and process development center and associated institutions like the national small industries Corporation Ltd. Central Institution of Tool Design, provide comprehensive assistance on all aspects of development to the small entrepreneur are provide annual advice on technical, economic, managerial and general matters. These services are outlined briefly in the next few paragraphs.

\subsection{Technical Services:}

These include extension services on improved technical process, guidance in production, planning selection of machinery, use of modern machines and process, preparation of factory lay-outs and designs material handling and common facilities services are provide through workshops and laboratories attached to the institutes and extension centers which include a tool room, machine shops, electroplating, heat treatment and testing facilities and so on. Models schemes, plant guides, feasibility reports, project reports, blueprints and drawings are also supplied at nominal cost.

\subsection{Marketing Services:}

These include provision of market intelligence for internal and external markets. Setting up of subcontracting exchange and trade centers, encouragement to small entrepreneurs to participate in Government stores purchase programmes, development of ancillaries, organization of exhibition, trade fairs, sponsoring of trade delegations etc.

\subsection{Economics Service}

These include extensive economic information services, industrial potential surveys, industry prospect sheet, feasibility studies, collection, maintenance and dissemination of statistical information.

\subsection{Managerial Services}

These services are aimed at improving the competitive strength of small enterprises through provision of problem oriented consultancy in industrial management in areas like financial management costing and production management.

\subsection{Training Services}

Special Training Programmes are organized in the various technical and management disciplines. Besides, the National Small Industry extension Training Institute, Central Institute of Tool Design, Central Tool Rooms. The Institute of Design and Prototype Development and Training Centers to the technical, Managerial and other training requirements of small entrepreneurs, officers of the SIDCO, State Directories of Industries, Field Level Officers, Banks and Financial Institutions and Associations of Small Scale Industries. 


\section{SWOT ANALYSIS}

SWOT is a combination analysis of four major attributes of an organization, programme or sector. These are strengths weaknesses, opportunities and threats. Strength refers to inherent abilities to compete and grow strong. Weaknesses are inherent deficiencies that cripple growth and survival. Strength and weaknesses are mostly internal. Opportunities are good chances and opening available for growth. These are environmental and external. Threats are externally wielded challenges, which might suppress inherent strengths, accelerate weaknesses, and stifle opportunities from being exploited.

SWOT analysis is presented for the SMEs sector enable to formulate of suitable strategies for revitalizing the sector to make it more vibrant. The aim of SWOT analysis is to identify the extent to which the current strategy of an enterprise and its specific strength and weaknesses, are relevant to, and capable of dealing with the challenges taking place in the business environment, particularly in relation to SME sector in the context of the liberalization, privatization and globalization which refer to a growing competitive environment, domestically as well as in international trade.

\section{PROBLEMS}

A survey of 100 SMEs were planned for this purpose purposive sampling technique is adopted, however 73 SMEs has responded to our questionnaire (response rate is 73\%) in and around Pune city of Maharashtra state and researcher has classified the problems of Micro and Small Enterprises in to six major categories namely;

\section{Market Structure Problems}

2. Logistic Problems

3. Managerial Problems

4. Economic Problems

5. Communication Problems

6. Socio-psychological problems

For the purpose of this study 25 important problems relating with marketing of SMEs were selected. These problems were put before the entrepreneurs. Responses were noted by means of classification, by means of ranking of the problems according the severities and significance felt by the respondents. In all a sample of 73 units asked the problem. This sample is the same as selected and used initially. This categorization was necessary because the same problem may be viewed by different angles by different categories of persons hence this classification.

The responses categorized as above and analyzed in the form of ranks were subjected to the weighted scores. On the basis of which percentage rating was calculated and ranks were allotted in ascending order i.e. the highest percentage was allotted the first rank and the lowest percentage was allotted the least rank. Conclusions were drawn on the basis of these ranks.

\subsection{Market Structure Problems}

The market structure means the general organization setup of the market. It includes following points.

\subsubsection{Market segmentation}

Which refers to the division of market into different segments formed on the basis of age group, sex group, income group, professional group, and so on.

6.1.2 The Degree of Competition: The structure of market is also decided by the degree of competition which can be classified in to three categories namely perfect competition, imperfect competition, and monopoly.

6.1.3 The Intermediaries: There are intermediaries acting in the marketing. These are the agents, brokers, adtiyas, etc.

The observations made by the researcher are presented in consecutives tables shown in the table 2

Table 2

Market Structure Problems

\begin{tabular}{|c|c|c|c|c|c|c|c|c|c|}
\hline \multirow[t]{2}{*}{$\begin{array}{l}\text { Sr. } \\
\text { No. }\end{array}$} & \multirow[t]{2}{*}{ Problems } & \multicolumn{5}{|c|}{$\begin{array}{l}\text { Ranking of } \\
\text { Problems }\end{array}$} & \multirow{2}{*}{$\begin{array}{c}\text { Weighte } \\
\mathrm{d} \\
\text { Score }\end{array}$} & \multirow{2}{*}{\begin{tabular}{|c|} 
Rating \\
Percenta \\
ge \\
\end{tabular}} & \multirow[t]{2}{*}{ Rank } \\
\hline & & 1 & 2 & 3 & 4 & 5 & & & \\
\hline 1 & \begin{tabular}{|c|} 
Intermediari \\
es and \\
Middle \\
Problems
\end{tabular} & 25 & 30 & 10 & 10 & 3 & 298 & 22.04 & 3 \\
\hline 2 & Competition & 30 & 20 & 25 & 4 & 14 & 327 & 24.18 & 1 \\
\hline 3 & Monopoly & 23 & 25 & 2 & 3 & 20 & 247 & 18.26 & 4 \\
\hline 4 & $\begin{array}{c}\text { Imperfect } \\
\text { Competition }\end{array}$ & 50 & 10 & 3 & 6 & 4 & 315 & 23.29 & 2 \\
\hline 5 & $\begin{array}{c}\text { Market } \\
\text { Segmentatio } \\
\mathrm{n}\end{array}$ & 8 & 5 & 10 & 25 & 25 & 165 & 12.20 & 5 \\
\hline
\end{tabular}

Source: Field investigation and survey.

It can also be observed from these tables that from the point of view of entrepreneur existence of intermediaries have not been viewed as a major problem. Intermediaries are necessary instruments for the entrepreneur. This problem is ranked third by entrepreneur responses. Further from the view point of entrepreneur competition is the major problem. It ranks first in the entrepreneur responses. The imperfect competition in the consumer market is viewed as of little lower significance and has received second rank in entrepreneur responses. The problem of monopoly is on the forth order and the problem of market segmentation has received the lowest rank of fifth order here.

\subsection{Logistic Problems}

Logistic covers supporting activities such as distribution, transportation, and warehousing. Marketing process in Maharashtra faces savior's problem of means of transportation. Generally the railway which is the low 
cost means of transpiration is not available in the rural area. Similarly, the roads connecting the rural places with the urban places are not very good. At many places the roads cannot be used during the rainy seasons. As a result goods cannot be transported to rural areas very easily Thus from the viewpoint of entrepreneurs transportation becomes the key problem.

Shortage of warehousing facilities is yet another hindrance. In rural areas sufficient warehouses are not there. The goods are stored in places subject to detritions by rain and sun. Further, there are no facilities of cold storage for protection of perishable goods.

Transportation and warehousing problems in combination create distribution problem. The researcher's observation regarding logistic problems based upon the responses given by entrepreneur are presented in table 3 .

Table 3

\section{Logistic Problems}

\begin{tabular}{|c|c|c|c|c|c|c|c|c|c|}
\hline \multirow{2}{*}{$\begin{array}{l}\text { Sr. } \\
\mathrm{N} \\
\mathrm{O}\end{array}$} & \multirow{2}{*}{ Problems } & \multicolumn{5}{|c|}{$\begin{array}{l}\text { Ranking of } \\
\text { Problems }\end{array}$} & \multirow{2}{*}{$\begin{array}{c}\text { Weighte } \\
\mathrm{d} \\
\text { Score }\end{array}$} & \multirow{2}{*}{$\begin{array}{c}\text { Rating } \\
\text { Percenta } \\
\text { ge }\end{array}$} & \multirow{2}{*}{ Rank } \\
\hline & & 1 & 2 & 3 & 4 & 5 & & & \\
\hline 1 & $\begin{array}{c}\text { Lack of } \\
\text { Transportati } \\
\text { on } \\
\end{array}$ & 28 & 28 & 10 & 4 & 3 & 293 & 32.95 & 2 \\
\hline 2 & Storage & 35 & 25 & 10 & 2 & 1 & 310 & 34.87 & 1 \\
\hline 3 & Distribution & 25 & 28 & 12 & 5 & 3 & 286 & 32.17 & 3 \\
\hline
\end{tabular}

It can be observed from the tables as well as the graphic presentation that from the viewpoint of entrepreneur's transportation is the main problem. All the respondent received second rank with reference to transportation problem. The first rank is received by the storage problem and third rank is received by the distribution problem. Thus logistic problems are having a common significance for entrepreneurs.

6.3 Managerial Problems

Management of SMEs marketing activities requires special skills. Success of market depends upon managerial skills. Management is getting things done through and with people. The major problem is created due to the differences in the outlooks of the entrepreneurs. The researcher has classified these problems into three categories.

\subsubsection{Market Support Problem}

The market support has different meanings for the entrepreneurs, market support means support of advertisement media, credit support, logistic support, and such other things. From the point of view of entrepreneurs it is either market information or availability of credit.

\subsubsection{Administrative Problems}

Administration in the market is little difficult. The workers are not educated. The consumers are also illiterate. As a result general market administration becomes very difficult.
6.2.3 Business Method Problems: The methods adopted in rural marketing cannot be the same as adopted in the urban marketing. Due to the fundamental differences in the situations. This includes issues like up keep of records, billing systems, credit system, weights and measures and so on.

The observations regarding these problems by researcher has been presented in analytic form in table 4 as well as their graphic translation shown on the adjacent page.

Table 4

Managerial Problems

\begin{tabular}{|c|c|c|c|c|c|c|c|c|c|}
\hline \multirow{2}{*}{$\begin{array}{l}\mathrm{Sr} \\
\mathrm{No}\end{array}$} & \multirow{2}{*}{ Problems } & \multicolumn{5}{|c|}{$\begin{array}{l}\text { Ranking of } \\
\text { Problems }\end{array}$} & \multirow{2}{*}{$\begin{array}{c}\text { Weighte } \\
\text { d } \\
\text { Score }\end{array}$} & \multirow{2}{*}{$\begin{array}{c}\text { Rating } \\
\text { Percenta } \\
\text { ge }\end{array}$} & \multirow{2}{*}{ Rank } \\
\hline & & 1 & 2 & 3 & 4 & 5 & & & \\
\hline 1 & $\begin{array}{l}\text { Market } \\
\text { Support }\end{array}$ & 20 & 22 & 18 & 5 & 8 & 260 & 30.09 & 3 \\
\hline 2 & $\begin{array}{c}\text { Administrat } \\
\text { ive } \\
\text { Problems }\end{array}$ & 32 & 26 & 10 & 2 & 3 & 303 & 35.06 & 1 \\
\hline 3 & $\begin{array}{l}\text { Business } \\
\text { Methods } \\
\text { Problems }\end{array}$ & 30 & 32 & 4 & 4 & 3 & 301 & 34.83 & 2 \\
\hline
\end{tabular}

Source: Field Investigation and survey.

It can be observed from table and graphs that managerial problem, as a hurdle to the rural marketing system remains same for the all entrepreneurs. All the respondent have allotted first rank to the administrative problems, second rank to the business method problems, and third rank to the market support problems.

6.4 Economic Problems

The marketing structure of SMEs suffers from a number of economic problems. Economic problems include problems related with the micro level i.e. the village and also at the Marco level and the economy as a whole. The Micro problem has been classified into three categories namely,

\subsubsection{Finance and Credit}

Availability of credit besides the purchasing power.

There can be no demand without purchasing power.

Rural market suffers from credit facilities. This is more

experienced by local entrepreneurs.

6.4.2 The problem of inventory

Decides the availability of the goods at the time when it is demanded. The inventory problem arises from problem of warehouse. Further this problem is connected with the availability of credit also because high-level stop means more investment.

\subsubsection{Turnover}

Rural market is not a fast moving market. New products under FMCG are introduced in the rural market. This creates turnover problems. Turnover problem is also associated with availability of finance/cash. There is good turnover when there is good crop and vice versa.

The Macro economic problem is associated with the process of liberalization, privatization, and globalization. India is participant of the Uruguay Round 
of GATT. As a result India adopted the new economic policy based upon the philosophy of free trade and lasseiz faire since 1992, the Indian economic policy has now been detached form the so called socialistic pattern of society adopted in the Directive Principles of State Policy of the Constitution of India. This has opened a gateway of Indian market to multinationals. Multinationals operating in FMCG area is introducing their products in rural market at a very fast rate. This is also creating new problems for the Indian rural market.

The researcher's observations regarding these economic problems are presented in table 6.5 which respectively show responses of entrepreneurs. The figures have also been translated in graphs. 5

\section{Table 5}

Economic Problems

\begin{tabular}{|c|c|c|c|c|c|c|c|c|c|}
\hline \multirow{2}{*}{$\begin{array}{l}\text { Sr. } \\
\text { N } \\
\text { o. }\end{array}$} & \multirow[t]{2}{*}{ Problems } & \multicolumn{5}{|c|}{$\begin{array}{l}\text { Ranking of } \\
\text { Problems }\end{array}$} & \multirow{2}{*}{$\begin{array}{c}\text { Weight } \\
\text { ed } \\
\text { Score }\end{array}$} & \multirow{2}{*}{$\begin{array}{c}\text { Rating } \\
\text { Percenta } \\
\text { ge }\end{array}$} & \multirow[t]{2}{*}{ Rank } \\
\hline & & 1 & 2 & 3 & 4 & 5 & & & \\
\hline 1 & \begin{tabular}{|c} 
Finance \& \\
Credit \\
\end{tabular} & 32 & 34 & 4 & 2 & 1 & 313 & 16.69 & 1 \\
\hline 2 & Inventory & 15 & 17 & 18 & 10 & 13 & 230 & 12.26 & 4 \\
\hline 3 & Turnover & 20 & 21 & 19 & 5 & 8 & 259 & 13.81 & 3 \\
\hline 4 & $\begin{array}{c}\text { Globalizati } \\
\text { on }\end{array}$ & 25 & 23 & 12 & 5 & 8 & 271 & 14.45 & 2 \\
\hline
\end{tabular}

Source: Field investigation and survey.

It can be observed from table and graphs that finance and credit problems have been rated first by entrepreneur whereas availability of credit have rated on the second scale. The entrepreneurs situated in urban places but operating in the rural area have given third grade to the financial problems. Thus it can bee seen that the finance is the main problem for entrepreneurs. Inventory problems are more faced by the urban dealer as a result the responses of entrepreneurs have rated the problem of inventory on the second scale,

The entrepreneurs face the problem of turnover more. They have the save rated turnover problem on third scale.

Globalization is slowly coming to the Indian market. But the problem is not far away. Entrepreneurs have put the problem on second scale of rank.

\subsection{Communication Problems}

Communication is one of the basic requirements of the market whether it is urban or rural. Communication establishes links between the seller and the buyers. A number of problems are connected with communication. The researcher has classified the communication problems in five categories namely, communication, media, branding, packaging, and market information. All these are different methods of communication using either word or picture for the purpose of communication. The results of the observations have been presented in the table 6 which show respectively the responses of entrepreneurs. The tables have also been translated into graphs.

Table 6

Communication Problems

\begin{tabular}{|c|c|c|c|c|c|c|c|c|c|}
\hline \multirow[t]{2}{*}{$\begin{array}{l}\text { Sr. } \\
\text { No. }\end{array}$} & \multirow[t]{2}{*}{ Problems } & \multicolumn{5}{|c|}{$\begin{array}{l}\text { Ranking of } \\
\text { Problems }\end{array}$} & \multirow[t]{2}{*}{$\begin{array}{c}\text { Weighted } \\
\text { Score }\end{array}$} & \multirow[t]{2}{*}{$\begin{array}{c}\text { Rating } \\
\text { Percentage }\end{array}$} & \multirow[t]{2}{*}{ Ranl } \\
\hline & & 1 & 2 & 3 & 4 & 5 & & & \\
\hline 1 & Communication & 20 & 15 & 15 & 10 & 13 & 238 & 19.14 & 3 \\
\hline 2 & Media Problem & 13 & 20 & 20 & 8 & 12 & 233 & 18.74 & 4 \\
\hline 3 & Branding & 25 & 18 & 12 & 8 & 10 & 259 & 20.83 & 2 \\
\hline 4 & Packaging & 8 & 25 & 10 & 10 & 25 & 215 & 17.29 & 5 \\
\hline 5 & $\begin{array}{c}\text { Market } \\
\text { Information }\end{array}$ & 32 & 28 & 5 & 3 & 5 & 298 & 23.97 & 1 \\
\hline
\end{tabular}

Source: Field investigation and survey

It can be observed from table and graphs that from the point of view of entrepreneur responses are concerned, market information problem receives the first rank, branding receives the second rank, communication problem the third rank, the media problem fourth rank and packaging fifth rank.

Thus it is observed that entrepreneurs have some problems in common as far as communication aspect is concerned.

\subsection{Socio-Psychological Problem}

Social set up of the rural area and psychology of rural inhabitant plays a very important role in the rural market. Indian rural population is a traditional society based upon class and caste and is having traditional opinions views, and approaches. All this has made the nature of rural market altogether different from urban market. Rural population is uneducated. Illiteracy still prevails in spite of different government programmes of literacy. Rural psychology thus plays a very significant role in defining the rural market structure. The researcher has classified the socio-psychological problems in to five categories namely illiteracy, tradition, mindsets, village structure and social structure. The observations are classified in table 7 , which represents the opinions of entrepreneurs. The same have been also translated into graphs.

It can be observed from the table and graphs that from the point of view of entrepreneurs the first rank is also 
received by the consumer mindset, second by consumer illiteracy, third by village setup, fourth rank by impact of village tradition and fifth rank by social setup.

Table 7

Socio-psychological Problems

\begin{tabular}{|c|c|c|c|c|c|c|c|c|c|}
\hline $\begin{array}{c}\text { Sr. } \\
\text { N } \\
\text { o. }\end{array}$ & Problems & \multicolumn{5}{|c|}{ Ranking of } & Weighte & $\begin{array}{c}\text { Rating } \\
\text { Problems }\end{array}$ & Rank \\
\cline { 3 - 9 } 1 & 1 & 2 & 3 & 4 & 5 & $\begin{array}{c}\text { Percenta } \\
\text { ge }\end{array}$ & \\
\hline 1 & Illiteracy & 28 & 25 & 18 & 2 & 0 & 298 & 20.18 & 2 \\
\hline 2 & $\begin{array}{c}\text { Impact of } \\
\text { tradition }\end{array}$ & 32 & 20 & 10 & 10 & 01 & 291 & 19.71 & 4 \\
\hline 3 & $\begin{array}{c}\text { Consume } \\
\text { r mind } \\
\text { setup }\end{array}$ & 32 & 28 & 8 & 3 & 2 & 304 & 20.59 & 1 \\
\hline 4 & $\begin{array}{c}\text { Village } \\
\text { Set up }\end{array}$ & 30 & 25 & 10 & 8 & 0 & 296 & 20.05 & 3 \\
\hline 5 & $\begin{array}{c}\text { Social } \\
\text { Set up }\end{array}$ & 25 & 20 & 13 & 8 & 7 & 287 & 19.44 & 5 \\
\hline
\end{tabular}

Source: Field Investigation and Survey.

\section{CONCLUSION}

Marketing problems of SMEs are discussed in the above paragraphs running a Small Scale Industries is a challenging task. The task is full of problems. Majority of these problems arise either because of traditional mindsets or infrastructural lacunas. The major problem is socioeconomic conditions and socio-psychological setups. Various problems faced by the unit owners of Small Scale industries have different weight age of different points of view Efforts need be made to bring out amiable solutions.

\section{REFERENCES}

[1] Dr. G Vijaya Bharathi, Dr. P. Subbalakshumma,

Mr. P. Harinatha Reddy "Promotion of Small Scale Industries- A Panoromic View." International Journal of Entreprise copmputing \& Business system. Vol.1,Issue $2^{\text {nd }}$ July ${ }_{P} .2$

[2] All India Manufacturers Organization, Growing Sickness in Industry - Principal Issue and Possible lines of remedial action.

[3] Bedabati Mohanty, (1986) : Economics of small Industries, Ashish Publishing.

[4] Bolton, J. E.,(1972): Report of the Committee of Inquary on Small Firms, Her Majestry's Stationary office. 